\title{
Bullets over Ballots: Islamist Groups, the State and Electoral Violence in Egypt and Morocco
}

\author{
Hendrik Kraetzschmar ${ }^{\mathrm{a} 1}$ and Francesco Cavatorta ${ }^{\mathrm{b} 2}$ \\ ${ }^{\mathrm{a}}$ Arabic and Middle Eastern Studies, University of Leeds, UK; ${ }^{\mathrm{b}}$ School of Law and \\ Government, Dublin City University, Dublin 9, Ireland
}

(Received June 2009; final version received August 2009)

\begin{abstract}
This article is concerned with state-sponsored electoral violence in liberalised autocracies. The first section of the paper identifies a number of variables that can help explain the decision calculus of authoritarian incumbents to deploy force against strong electoral challengers. The second section then examines these propositions with reference to Egypt and Morocco. Drawing on recent parliamentary elections in both countries the article questions why, despite facing the challenge of political Islam, the two regimes differed so markedly in their willingness to manipulate the polls by recourse to violence. Whilst the Egyptian authorities decided to abrogate all pretence of peaceful elections in favour of violent repression against the Muslim Brotherhood candidates and sympathisers, no such tactics were deployed by the ruling elite in Morocco. We suggest that three principal factors influenced the regimes' response to this electoral challenge: (1) the centrality of the elected institution to authoritarian survival, (2) the availability of alternative electioneering tools and (3) the anticipated response of the international community. The article concludes by suggesting that in order to understand better when and how states deploy violence in elections, we need to focus on a more complex set of factors rather than simply on the electoral potency of key opposition challengers or the authoritarian nature of the state.
\end{abstract}

Keywords: state-sponsored electoral violence, liberalised autocracies, Morocco, Egypt

\section{Introduction}

The phenomenon of violence in elections is one of many paradoxes with which political scientists have to grapple. Whilst theoretically the notions of elections and violence seem incompatible, in practice they often go hand in hand. Multiparty elections epitomise efforts at managing political conflict by non-violent means, and are commonly regarded as the ultimate remedy for conflict in society. Yet reality is

\footnotetext{
${ }^{1}$ Email: h.j.kraetzschmar@leeds.ac.uk.

${ }^{2}$ Email: Francesco.Cavatorta@dcu.ie.
} 
often multifaceted, with outbursts of violence accompanying elections at various stages of the process, either in the lead-up to, during or in the aftermath of polling day.

The phenomenon itself is as old as the electoral principle. It was as much a feature of elections in ancient Rome, the Victorian era and nineteenth century America, as it sadly remains in modern times. ${ }^{1}$ Acts of violence causing death and destruction have in the past marred elections in countries across continents and different political systems, and continue to do so. And yet the phenomenon has evoked limited scholarly interest. As Rapoport and Weinberg remark, despite a plethora of research on political violence, there is a paucity of comparative studies on its 'little brother', electoral violence. ${ }^{2}$ The only analyses at hand are those by Rapoport and Weinberg themselves and a number of studies addressing the issue of electoral violence in conflict and transitional settings. ${ }^{3}$ Even less is available when it comes to the phenomenon of state-sponsored electoral violence. A few case studies apart, no academic work exists which broadly explores the question of when and why states resort to coercion in elections. ${ }^{4}$

In keeping with the theme of the special issue, this article examines the third area of research spelled out by Schwarzmantel in his introductory contribution: 'violence as a challenge to democracy'. According to Schwarzmantel this challenge carries two dimensions. As far as liberal democracies are concerned the challenge of violent politics emanates primarily from social movements seeking better inclusion and recognition within the polity, whilst in non-democracies or in liberalising countries where uncertainty over the process is high it is often the regime itself which resorts to violence as a means of securing authoritarian survival.

Focusing on the later scenario, this article explores state sponsorship of political violence in elections with a specific focus on the Arab world where we can observe, paradoxically, both the persistence of authoritarianism and a significant increase in electoral contests. The article puts forward a number of variables that can help explain why and when authoritarian incumbents deploy violent electioneering tactics as a means of 'carving the democratic heart out of the electoral contest'. Essentially, we suggest that one ought to look beyond the nature of authoritarianism and the electoral potency of opposition challengers to understand the conditions under which states are likely to resort to such tactics. Three factors are identified that may explain state sponsorship of electoral violence. First, we focus on the institutional 
framework in a given country and consider the centrality and effective policy-making powers of the elected institutions for authoritarian elites. How important is the institution for which elections are held? Second, we explore the availability of alternative electioneering devices falling short of the resort to force, and how the regime employs such alternatives to manage the election process. Finally, we emphasise that domestic decision-making takes into account the anticipated response of the international community to the use of electoral fraud in general and of electoral violence in particular.

This theoretical framework is then examined in the context of recent parliamentary elections in Egypt (2005) and Morocco (2007). The two cases lend themselves to an exploratory analysis of state-sponsored election violence for a number of reasons. To begin with, they are both authoritarian countries with a liberalising agenda and can be defined as 'liberalised autocracies. ${ }^{6}$ Second, they are representative of the political dynamics in many countries across the Arab world where existing regimes are somehow able to survive despite the lack of popular legitimacy and the presence of a strong Islamist opposition. Third, the two countries, like many others in the region, have increasingly taken elections seriously over the last decade because of both domestic and international pressures for reform. Finally, the two countries are paradigmatic of the two types of regime we find in the region. Morocco represents the political and institutional dynamics that we find in Arab monarchies where rulers are unelected and where legitimacy can be characterised as 'traditional.' Egypt exemplifies the manner in which politics takes place in authoritarian republics where 'strong' presidents are elected and have to deal with specific electoral constraints. This allows for an examination of how electoral contests occur in the two countries and how authoritarian incumbents respond to strong challengers at the ballot box.

\section{Electoral potency, threat perceptions and state-sponsored violence in authoritarian elections}

This article adopts a simplified decision-theoretic approach to the study of statesponsored violence in authoritarian elections. It assumes that authoritarian incumbents are rational actors whose principal objective is to remain in power and whose decision to resort to, tolerate or refrain from violence against political opponents is a strategic choice amongst many to ensure regime survival. State-sponsored violence is thus 
neither irrational nor indiscriminate, but constitutes a course of action that is deliberate and usually targeted at opposition forces perceived as posing a most serious threat to authoritarian incumbency.

We define electoral violence as acts or threats of coercion, intimidation or physical harm perpetrated to affect the process and/or outcome of an election. The instigators of such violence can include both state actors (police, secret services, armed forces) and non-state actors (e.g. political parties and guerrilla, rebel or paramilitary groups). Where the former is involved we are dealing with so-called state-sponsored electoral violence. This is a form of political violence instigated either directly by the state authorities or by regime proxies, such as militias, ruling parties, regime-hired troublemakers, and so forth. Following Gartner and Regan ${ }^{7}$ we have included regime proxies in our definition of state-sponsored violence based on the assumption that the central authorities hold significant sway over these agents and their actions.

With few exceptions, it appears that most instances of state-sponsored electoral violence occur in non-democratic regimes. ${ }^{8}$ Illustrative cases in point are the coercive tactics recently employed by authoritarian incumbents in elections in Zimbabwe (2008) and Ethiopia (2000). ${ }^{9}$ For these regimes, as for any electoral autocracy, authoritarian survival in a liberalised environment is of paramount concern, and resorting to violence in elections constitutes one of several illegitimate strategies to secure this survival at the ballot box. Alongside ballot fraud and vote buying, brute force, or the failure to prevent it, is often used by the authorities and/or their proxies to distort the electoral competition in favour of regime-supportive forces and to quell any post-election outburst of popular anger at the rigging of the election result, as happened for instance in the aftermath of the 2009 presidential poll in Iran. Acts of regime-perpetrated electoral violence can take various forms, ranging from targeted killings of prominent opposition figures, the physical disruption of opposition rallies, the beating and/or arbitrary arrest of opposition candidates and sympathisers, to coercive measures aimed at preventing voters from casting their ballots.

When deployed by authoritarian incumbents, the overall objectives and targets of state-sponsored violence in elections are thus relatively easy to discern. Usually the overriding aim is to neutralise key electoral challengers and the targets of such violence are those opposition forces perceived as posing the greatest threat to the electoral status quo. What is more difficult to determine however, and of interest here, 
is the decision-calculus that drives authoritarian elites to use force as an electioneering tool in the first place, particularly as it is the regime itself that has decided on holding multiparty elections. Is it possible to predict a state's propensity to resort to violence in elections? If so, when and how do authoritarian incumbents determine that the benefits of deploying force outweigh both the loss of domestic legitimacy that invariably goes hand in hand with this repressive strategy, and the possible ire of the international community?

For authoritarian rulers the very notion of opposition is suspect and treated as a potential or real threat to regime survival. Obviously, the degree to which autocrats tolerate political opposition is contingent on the nature of authoritarianism (closed vs. competitive autocracies) and the types of demands articulated by their opponents. ${ }^{10}$ Pliant and weak opposition parties, for instance, which are allowed to garner a limited number of seats in parliament in return for their aquiescence in the existing order, pose no serious electoral challenge to incumbent regimes and are thus essentially nonthreatening. In fact, some scholars have argued that, where allowed to operate, these opposition forces help sustain a veneer of democratic governance within inherently autocratic structures and as such prolong rather than endanger regime survival. ${ }^{11}$ The situation may change dramatically, however, wherever the electoral potency of the opposition is enhanced, that is where non-regime forces show any real sign of grassroots support, organisational capacity, and/or willingness to challenge the boundaries of acceptable dissent. In these circumstances then, authoritarian incumbents are faced with real challengers at the ballot box.

At first glance it therefore appears that electoral potency features critically in the decision-calculus of autocrats to use force against challengers in elections. And indeed, with the electoral equilibrium under threat, authoritarian governments may be tempted to deploy repressive means to sustain the electoral status quo. Yet electoral potency on its own cannot explain the choice of violence. One could, for instance, conceive of a strong opposition being allowed to do well in elections simply because the institution for which parties are competing is constitutionally relatively powerless. Equally, one could think of the role that political parties actually play in any political system, contrasting regimes reliant on a ruling party to ones based on unelected decision-makers such as monarchs. These regimes may inevitably view electoral competition and its challenges very differently and thus diverge in their readiness to resort to force during an election. 
It is thus apparent that other important factors must be considered in order to fully understand the decision-making rationale of authoritarian incumbents in resorting to violence in elections. As mentioned earlier, we propose three variables that may help explain when electoral potency turns into an electoral threat which from the regime's point of view warrants violent repression. The first variable to examine is the centrality for authoritarian survival of the institution for which parties and candidates are competing. Authoritarian rulers have to identify the importance of the institution and decide whether losing power within it would undermine significantly their legitimacy and ability to rule unhindered. It becomes therefore important to determine where the particular institution is located in terms of its constitutional relevance. Accordingly, in a political system where the executive and legislative powers are elected and mutually interdependent, the stakes of electoral competition are quite high because the authoritarian incumbent could conceivably have much to lose if a strong opposition were to take advantage of even limited openings. This has been the case for instance in Algeria in 1990 when the Islamic Salvation Front (known by its French acronym FIS) won the legislative elections. The number of seats it won would have given the party the possibility to change the constitution. The Algerian parliament was therefore a very significant institution and its 'loss' to the Islamists was countered with significant violence. Conversely, in the context of a political system where the main executive institution is beyond electoral politics, as in executive monarchies, electoral competition for the legislature might not constitute a significant challenge to the authoritarian incumbent because formal legitimacy derives from other sources. Thus, a monarch might be more willing and even encourage effective pluralism. ${ }^{12}$ The Jordanian elections reflect this logic, as supreme executive powers are in the hands of the monarch who uses parties in parliament to selectively support his policies.

The second factor to examine concerns the nature of the electoral contest itself and the tools available to incumbents to influence its outcome. Elections in authoritarian systems have the overarching objective of fostering regime legitimacy, but they can be either threatening or legitimising. ${ }^{13}$ Threatening elections mean that authoritarian incumbents have been forced to open up the political system defensively due to either domestic or external pressures or both, and the electoral competition becomes therefore a potentially dangerous test of popularity. The ruling elite in this case is very aware of the potentially snowballing effects of such elections if they do 
not deliver results that make survival possible, and is willing to influence the outcome with all the means at his disposal, including violence. On the contrary, legitimising elections serve the purpose of demonstrating the existence of political pluralism, and whilst incumbents also attempt to control the results, such results do not have the same significance. First the regime's legitimacy rests elsewhere and, second, it is precisely by allowing a degree of effective pluralism that incumbents derive both domestic and international benefits. In this case the instrument of violence would be damaging to the survival of the regime because it would indicate that the other tools to remain in power are no longer effective.

The third and final factor has to do with the international response which authoritarian elites must anticipate when deploying force against political opponents. For authoritarian regimes the recourse to violence as an electioneering tool not only carries domestic risks, but can also incur significant external costs. These costs can range from moral condemnation to the withdrawal of vital economic and military aid, the suspension of bilateral/multilateral trade agreements or the imposition of economic and/or political sanctions. ${ }^{14}$

No liberalising regime that breaches the norms of electoral good governance is likely to escape some form of international condemnation. In the past, Western governments have on numerous occasions issued statements reminding the regimes in question of their commitment to free and fair elections. The real issue, therefore, is not so much whether offending regimes will be reprimanded, but whether key Western allies are prepared to impose negative sanctions in order to pressure authoritarian incumbents to improve their rights record in elections. Two factors may play into the decision of whether and when Western governments are prepared to do so. First, it may depend on whether or not regime repression is perceived as a democratisation-threatening or a democratisation-saving exercise. If it is the latter, then some form of repression against political opponents, including the use of force, may be tolerated and would not damage the overall democratising legitimacy of authoritarian incumbents. Second, Western governments may also shy away from deploying negative sanctions against regimes considered 'pivotal states' in a geostrategic sense. ${ }^{15}$ Here again, authoritarian stability and the survival of a pro-Western government may outweigh any concern for democratic reforms, particularly if such reforms would benefit forces perceived as inherently anti-Western. In both scenarios then, the external costs of violent repression are likely to be short-term and limited, 
and unlikely to damage the rulers' overall credentials as democratising regimes or their strategic partnership with the West.

\section{Regime violence in Egypt's 2005 parliamentary elections}

Egypt last went to the polls in autumn 2005 to elect a new president and lower house of parliament. The months leading to the polls were marked by an air of measured optimism that the voting experience would be qualitatively different from past elections. Whilst no-one assumed that Mubarak would lose the presidency or the ruling National Democratic Party (NDP) its stranglehold over the legislature, developments in and outside the country nonetheless suggested that this time around there would be no 'election-business as usual'. Confronted with an emboldened reform movement at home and a US administration eager to see Egypt take a lead in regional democratisation efforts, the regime found itself under unprecedented pressure to organise clean and peaceful elections. ${ }^{16}$

At first, this pressure appeared to be having the desired effect. In February 2005 Mubarak unexpectedly announced a reform of the presidential election law, opening the presidency to multi-candidate contestation. The elections themselves, which took place on September $7^{\text {th }}$, were hailed by the international community as a significant step towards democracy and seen as evidence that Mubarak was committed to cleaner elections. Observers lauded the calm and overall openness that prevailed throughout the campaigning period and on polling day itself, and commented positively on the fact that opposition candidates were allowed to campaign relatively unhindered. ${ }^{17}$

Little over a month later, the parliamentary election campaign seemed to kickoff to a similarly encouraging start. Yet again the regime appeared more relaxed about opposition activism than in the past, granting it an exceptional margin of freedom during the campaigning period. Even the Muslim Brotherhood, long vilified by the government, enjoyed unprecedented freedom during the campaign, with the group's candidates and cadres being allowed to canvass their message relatively openly and without the usual government interference and intimidation. ${ }^{18}$ It thus appeared that the upcoming poll would run peacefully and that the new legislature would be more pluralist than its predecessors. 
This was not to be, however. Far from passing peacefully, Egypt bore witness to an election that was marred by the most serious outbreak of political violence since the 1995 parliamentary poll. By the time the polling stations closed on 9 December 2005, the elections had cost 11 lives and left over 500 people wounded in scores of violent clashes. ${ }^{19}$ According to observers on the ground, most of the violence took place in rounds two and three of the voting and involved in a vast majority of instances the Egyptian security forces and NDP-hired trouble-makers on the one side and Brotherhood candidates and their supporters on the other. ${ }^{20}$ In fact, the ferocity with which this violence pitted the regime and its proxies against the Islamist opposition constituted a sad hallmark of the 2005 parliamentary elections. Whilst not immune to regime interference, none of the other opposition parties contesting the elections were party to, or the target of, the scores of clashes that occurred between regime and Islamists. ${ }^{21}$

This raises the question of how to explain the sudden and unexpected outburst of political violence in the later phases of the 2005 parliamentary elections. To be sure, election-related violence is not uncommon in Egypt, and by comparison the 2005 parliamentary poll was not even the most bloody. What is so remarkable about these elections and in need of explanation, however, is the fact that the violence broke out so late in the election process and that it stood in sharp contrast to the relative quiet and openness that had prevailed during the campaigning period.

Table 1: Casualties of electoral violence, 1995-2005

\begin{tabular}{lcr}
\hline Parliamentary Elections & Deaths & Injured \\
\hline 1995 & 80 & 1,500 \\
2000 & 10 & 64 \\
2005 & $11-13$ & 500 \\
\hline Sources: Thabet, H. G. 2006. 'Egyptian & Parliamentary Elections: & Between \\
Democratization and Autocracy.' African Development 31/3, p. 19; & Egyptian \\
Organisation for Human Rights, Future Parliamentary Victims: EOHR's Report on \\
Fact-Finding Mission to Monitor Results for 2005 Future Parliamentary Victims in the \\
Governorates, Cairo: 30 January 2006, http://www.eohr.org/report/.
\end{tabular}

As far as state involvement is concerned, we posit that the use of force by the security services and NDP trouble-makers was calculated and targeted against the opposition group posing the gravest electoral threat to ruling party candidates. For the regime this threat emanated from the Muslim Brotherhood (MB) which, by virtue of its exceptionally strong showing at the ballot box, endangered the NDP's stranglehold over the legislature, which thus constituted such a key pillar of authoritarian survival. 
Another important factor was that from the regime's point of view the use of force against the MB was deemed both necessary and viable. It seemed necessary because so late in the election process the regime had run out of alternatives to turn the situation around and manufacture an NDP landslide. It was considered viable, because in this particular instance Cairo's domestic threat perceptions coincided with American security concerns over rising 'Islamist extremism' in the region, which meant that Egypt was unlikely to come under fire from Washington over the deployment of repressive force against the Brotherhood and its sympathisers.

It is widely recognised that the Muslim Brotherhood constitutes by far the most potent political threat to the regime. ${ }^{22}$ For Mubarak the MB has long lost its utility as a bulwark against leftist forces, and is nowadays regarded as a serious menace to the regime. Not only is the group greater than other opposition parties in its resource capacity (both human and financial), organisational reach and ability to muster grass-roots support, but also in the assertiveness with which it challenges the secular foundations of the Egyptian regime and its pro-Western foreign policy. ${ }^{23}$ Tethering perilously close to the red-lines of 'acceptable opposition behaviour', the Muslim Brotherhood is thus susceptible to regime repression. ${ }^{24}$

Whilst a total crackdown on the group has never been on the cards - primarily because this would drive the Islamists underground and cut off millions of Egyptian citizens from vital social services provided by the group - the authorities have always made it clear that serious MB forays into national politics would not be tolerated. The regime remains fiercely opposed to the notion of a legalised Muslim Brotherhood party and, although in past elections it did allow MB members to stand as independents, it has taken great care to contain their electoral potency. ${ }^{25}$ In the legislative elections of 1995 and 2000, for instance, the group was subjected to a systematic and unrelenting clampdown on its candidates and supporters. As a consequence of this and other forms of regime-perpetuated electoral malpractice, the group has had little success in translating its support on the Egyptian street into a meaningful presence in parliament. In 1995 the MB won just one and in 2000 seventeen of the 444 elective assembly seats. ${ }^{26}$

However, with the authorities showing greater leniency towards the Brotherhood in the 2005 parliamentary election campaign, the group's electoral fortunes improved dramatically. Early signs that MB candidates were benefitting en masse from less government interference transpired in the first round of voting, by the 
end of which the group had captured 34 of the 164 available seats. ${ }^{27}$ For the MB this was a remarkable success, given that 67 percent of its candidates had won their electoral contests and that so early on in the polling process the group had already doubled the number of its representatives in the Egyptian legislature.

The regime meanwhile must have read these first-round results with some alarm. Not only had the NDP fared relatively poorly, capturing 'just' 112 of all available seats, ${ }^{28}$ but there was a real danger that similar Brotherhood inroads in the rounds to come would cost the ruling party its two-thirds majority in parliament. As will be discussed below, this considerable majority has been critical to the survival of the Mubarak regime ever since the turn to multiparty politics. ${ }^{29}$ The danger of losing this majority then turned into a realistic prospect in the second round of voting, which still left the NDP 108 seats short of the 303 mandates needed. To defend its hegemonic position in the legislature, the NDP thus needed to capture at least 80 percent of the remaining seats in the final round of voting, a percentage it had fallen far short of in rounds one and two. As documented in table 2, in the first round of voting the NDP won 68 and in the second round just 58 percent of all elective seats. The Brotherhood by contrast appeared to be on track to win a historic number of mandates, capturing a further 42 seats in the second phase of the polls. With the electoral tide turning against the NDP, and time running out, the regime thus felt compelled to revert to a well-tested strategy of violent repression in order to block any further Brotherhood inroads and secure election victory. ${ }^{30}$ Discounting the damage this sudden outburst of violence has done to the reform credentials of the Egyptian regime, it appears to have aided the NDP in securing the 303 mandates needed to retain its two-thirds majority in parliament.

Table 2: NDP \& MB inroads by voting phases (I - III)

\begin{tabular}{lrrrrr}
\hline & \multicolumn{2}{c}{ NDP Gains } & \multicolumn{2}{c}{ MB Gains } & \multicolumn{2}{c}{ Total No. of } \\
Seats
\end{tabular}

Source: Konrad Adenauer Foundation, Die Aegyptischen Parlamentswahlen 2005: III. Wahlgang, 22 December 2005, http://www.kas.de/proj/home/pub/18/1/year-2005/dokument_id-7763/index.html.

${ }^{1}$ Including NDP Independents.

${ }^{2}$ Includes only directly elected seats. 
The determination of the Egyptian authorities to defend by all means necessary the NDP's two-thirds majority in 2005 underscores the high stakes nature of legislative elections in presidential autocracies. In Egypt, parliament is constitutionally endowed with significant legislative and oversight powers which, if left unchecked, can seriously endanger the foundations of authoritarian rule. To prevent this from happening, and ensure parliament remains de facto subservient to the political executive, the regime relies on the NDP and its capacity to win two-thirds majorities at the ballot box. With this majority secured, Mubarak was able in the past to control the plenary debates and committee work in parliament and ensure that the opposition lacks the numerical strength to obstruct the passage of critical government legislation or to push through liberalising reforms, censor cabinet ministers or impeach the president. ${ }^{31}$ Crucially also, over the past three decades it has allowed Mubarak to govern by emergency rule, which must be granted and periodically renewed by the lower house of parliament with a two-thirds majority. ${ }^{32}$ Whilst the constitutional powers of the presidency are vast, these emergency provisions have endowed Mubarak with important additional tools to regulate and control political life without appearing illegal. Emergency powers allow the president to govern by decree, suspend basic civil liberties, censor the press and detain regime critics without trial, all for the 'good' of safeguarding national security and public order. ${ }^{33}$ In actual practice, of course, the regime has deployed most of these powers to tackle domestic opponents, including most prominently the Muslim Brotherhood. ${ }^{34}$ Critical to authoritarian survival, the capacity to govern by emergency rule was thus to be defended at all costs, if needed by resort to illegitimate vote-gaining strategies.

As for the question of why the regime resorted to violence, the decision must be interpreted as a measure of last resort, conditioned by the absence of viable alternatives to manufacture desired election outcomes so late in the voting process and the minimal external costs this repressive strategy appeared to inflict on the Mubarak administration. As far as the former is concerned, it is likely that the unavailability of tawzir (ballot fraud) critically shaped the regime's decision calculus to relinquish its commitment to peaceful elections. Ballot fraud, or ballot-box stuffing, is not only common in authoritarian elections, but where available, constitutes a most effective tool to correct unexpected and/or undesired opposition inroads until very late in the election process. In the event, however, the presence of judicial supervision rendered it very difficult, if not impossible, for the Egyptian authorities to resort to this 
illegitimate electioneering device. Full judicial supervision had been introduced by the regime in 2000, following a Supreme Constitutional Court (SCC) ruling that declared unconstitutional the practice of staffing ballot stations with government employees. ${ }^{35}$ With both the casting and counting of ballots outside its direct control, the regime in 2005 seemed starved of options to 'correct' the results in favour of the ruling party.

The regime thus found itself caught between a rock and a hard place. Letting the election run its course could cost the NDP its two-thirds majority and land it with a potent opposition block in parliament. Resorting to dirty electioneering tactics to 'correct' the election results, including the use of force, on the other hand, would further undermine the regime's legitimacy at home and tarnish Mubarak's carefully rebuilt image as a reform-minded leader abroad. In the end, the regime opted for what it must have perceived as the lesser of two dangers to authoritarian survival, cracking down harshly on the MB, its candidates and sympathisers.

This decision was paired with the knowledge that a violent clamp-down on the MB would not carry any negative repercussions for Cairo's close strategic relation with the USA. For although the Bush administration had singled out Egypt as a vanguard in renewed efforts to push for democratisation in the region, it was apparent that Washington did not wish to see the Mubarak regime replaced by an Islamist-led government that openly opposes peace with Israel and objects to Cairo's close relations with the US. ${ }^{36}$ For the Bush administration democratic alternance was not desirable at any cost and certainly not when it threatened to jeopardize Cairo's position as a pro-Western status quo power, a key arbitrator in the Middle East peace process and a vital ally in the global fight against Islamist terrorism. ${ }^{37}$

A clear indication of this caveat to US democracy promotion in Egypt can be found in the pronouncements made by Bush administration officials during the 2005 parliamentary elections. Indeed, despite the apparent heavy-handedness of the Egyptian security forces against the MB in the second and third rounds of voting, the US State Department showed little willingness to condemn the violence publicly, let alone exert any normative or material pressure on Mubarak to comply with his promise of 'free elections'. ${ }^{38}$ Instead US officials reiterated the view that Mubarak was committed to the pursuit of peaceful elections and that Washington had no reason to question this commitment. ${ }^{39}$ What is more, State Department officials sounded remarkably similar to the official position taken by the Egyptian leadership. Explicit 
reference to the Brotherhood was avoided and its impressive showing at the ballot box essentially overlooked. For Washington, as for Cairo, it was not the group that had participated and won a significant number of seats in parliament - given that they were outlawed as a political party - but independent candidates with no party or ideological affiliation. ${ }^{40}$

Because the US and Egypt saw eye to eye on the threat posed by the Brotherhood, the Mubarak regime rightly assumed that Washington would impose few external costs on any efforts to contain the group's electoral inroads. Indeed, beyond limited condemnations of its election management (something the regime could weather) the Bush administration never signalled that it would review its annual economic and military aid to Egypt, let alone impose sanctions in response to the evident manipulation of the parliamentary poll. For the US, turning a blind eye to Egypt's heavy-handedness was thus seen as the 'lesser of two evils' in comparison to the prospect of a significantly emboldened Islamist group in parliament.

In summary, the state's recourse to violence against the MB in the later phases of the 2005 parliamentary poll highlights a number of important facts about the current state of Egyptian politics. First, it underscores the doubtful commitment of the Mubarak regime to clean elections and more broadly to the pursuit of democratic reforms. Indeed, it yet again illustrates that pledges of reform will remain just that when critical pillars of authoritarian survival are under attack. Second, it reveals the potency of the Muslim Brotherhood as a serious electoral challenger to the regime, and the regime's apparent incapability to tackle its electoral ascendancy by political means. Finally, it illustrates that as long as the political threat emanates from forces hostile to the US and to close US-Egyptian relations, Washington is unlikely to pursue more aggressively its democracy promotion agenda in the Arab world. ${ }^{41}$ If anything, the new Obama administration is likely to reduce even further the pressure of democratisation on Arab allies, given the president's belief in refraining from heavily interfering in the domestic politics in the region.

\section{Regime manipulation without violence: Morocco's 2007 parliamentary election}

Two years after Egypt, on September $7^{\text {th }} 2007$, Moroccans went to the poll to elect a new lower house of parliament. There was a significant degree of expectation both domestically and internationally about these elections for two important reasons. First, the elections were meant to confirm the steady progress towards democratization that 
the Kingdom had been making for at least a decade, with the King himself presenting them as a watershed. Second, most analysts had predicted that the Islamist Justice and Development Party (PJD) would top the polls and there was considerable curiosity as to how the King and the Makhzen, which represents an informal governing alliance between the monarch, his advisers, selected businessmen, high-ranking bureaucrats and tribal chiefs operating as the unelected and unaccountable decision-maker in the country beyond the control of the elected government, would deal with this scenario. Whilst it should be kept in mind that the PJD is generally considered not to be antagonistic to the Monarchy, a very high electoral score might have emboldened those within the party who would be eager to display a much more forceful opposition to the current policies. In any case, it should be underlined that since its entry into electoral politics, the PJD has never joined governing coalitions, maintaining therefore a degree of distance from both the monarchy and the other political parties.

On a superficial level, the same domestic and international constraints that applied to the Egyptian case were also present in Morocco. The international community expected the elections to demonstrate that external support for the Monarchy was well founded because King Mohammed VI was indeed moving the country towards democracy. Domestically, the elections were lauded as the culmination of a process of socio-political change that had seen the King push for a progressive liberal reform of the family code, the expansion of a range of civil liberties and the creation of a reconciliation commission to investigate past human rights abuses. ${ }^{42}$ The Kingdom would finally move towards substantial political reforms, the missing element so far in Mohammed VI's liberalising agenda.

The strategy of including Islamist groups into the political and institutional game had been a 'risk' that King Mohammed VI's predecessor, Hassan II, had been willing to undertake in order to avoid the 'Algerian scenario', and he proceeded to include the PJD in the parliamentary scene. Mohammed VI continued his father's policy towards the PJD and the party ran in a limited number of constituencies in 2002 showing considerable strength. ${ }^{43}$ In 2007 the PJD was allowed to run in all constituencies and it was tipped as the inevitable frontrunner. Indeed, most observers and the leaders of the other parties expected it to win a clear plurality of both votes and seats, and members of the PJD itself were confident of topping the polls, claiming that they were "able to obtain 70 seats. ${ }^{44}$ Obviously, there was no question of the PJD winning an absolute majority of the 325 seats in parliament, but even winning the 
largest share of seats would have caused considerable domestic and international anxiety.

The election campaign officially started only two weeks before polling day and it displayed a very interesting feature: the strong involvement of the state in trying to boost participation without openly taking sides with any of the parties in competition. The mobilisation of the electorate included 'commercials urging youth to fulfil their national and social duty' and travelling caravans in the countryside to increase voter turnout. ${ }^{45}$ This demonstrates that the King and the Makhzen had a great interest in the success of the parliamentary poll because it would reinforce the positive external perception of the regime and the self-perception of the ruling elites as democratising ones. It is also for this reason that the state apparatus refrained from meddling with the electoral process, thus turning the election into what Storm describes as the 'most competitive, free and fair in the country's history' ${ }^{46}$ The positive sanctions obtained from the international community and from independent monitors also confirm the view that the 2007 elections were indeed a watershed for Morocco in terms of freedom and fairness. ${ }^{47}$

The proactive role played by the authorities to ensure the elections would pass off peacefully and the absence of any interference in the electoral process by the state contrast sharply with the Egyptian experience in 2005, although there was significant gerrymandering and toleration of a degree of vote buying. Mohammed VI considers elections an important legitimising exercise, but a predicted landslide by the PJD was a significant risk as it could expose the weakness of the regime. How then does one explain the King's gamble of holding reasonably free and fair elections in the face of the expected victory of an Islamist party, which had traditionally sat in opposition and had been indicated as morally responsible for the wave of terrorism that Morocco experienced in 2003 and 2004? Upon closer inspection, it emerges that the anticipated landslide victory of the PJD, which ultimately did not materialise, was not perceived as overly problematic for the King and his advisers for a number of reasons.

First of all, legislative elections in Morocco are not very meaningful because they do not fundamentally shift the balance between elected representatives and the royal palace. As mentioned previously, this is not the case in Egypt where the legislature and the executive have a mutually sustaining relationship. Whilst Denoeux posits that the Moroccan legislature is not as toothless as the literature argues and that it 'is making growing contributions to political representation and executive branch 
oversight', ${ }^{48}$ there is no doubt that without far-reaching constitutional reforms the executive powers of the King severely limit the chamber's influence in the political system. ${ }^{49}$ For instance, the King is responsible for appointing the prime minister, but he does not have to choose the leader of the party topping the poll for this post. More significantly, the King appoints the most important ministers, including Interior and Foreign Affairs. These and other constitutional prerogatives make elected officials unable to affect significantly the policy-making process because most of the input for policy comes directly from the palace or indirectly from the King-appointed ministers. ${ }^{50}$

Second, Moroccan elections, including those of 2007, are carefully managed by the Palace. While it is true that the 2007 contest represented the freest and fairest ones in the Kingdom's history, such elections are not immune from interference. Thus, the Palace was able to gerrymander the electoral districts, favouring the overrepresentation of the countryside, in order to ensure that the parties loyal to the Monarch (les parties $d u$ Roi) do well. Also, vote buying was largely tolerated. These two instruments were sufficient in many ways in 2007 to manipulate the outcome of the elections before they even took place. In addition to these direct tools of interference, there are other traits of the Moroccan political system that reinforce the ability of the Palace to tolerate and even encourage the participation of potentially threatening parties. For example, as Storm convincingly demonstrates, 'not since the first Moroccan parliamentary elections in $1963 \ldots$ has a political party been able to obtain more than $15 \%$ of the valid votes cast', ${ }^{51}$ indicating that the fragmentation of the Moroccan party system prevents parties from reaching high individual scores. The Moroccan polity is characterised by a tradition of multi-party politics with a number of significant cleavages. In the absence of either overt coercion or widespread electoral fraud, the 2007 elections simply reflected divisions within Moroccan society and the peculiarity of the electoral system which encourages fragmentation. This sharply contrasts with the Egyptian party system where the dominant party functions as a transmission belt between the presidency and society. In Morocco, political parties are technically independent from the executive monarchy, suffering from what Willis terms 'the illusion of significance'. ${ }^{52}$ They operate in a context where the King relies on the wider Makhzen to consolidate his power.

Another important factor allowing the Palace to be 'relaxed' about the electoral process is that political Islam in Morocco is not represented primarily by the 
PJD and therefore both its participation in the electoral process and its score should be analysed in this context. Political Islam in Morocco is varied with at least three broad trends represented. ${ }^{53}$ There is the participatory moderate trend of the PJD, which has accepted the primacy of the King in the political process and therefore 'does politics' within the limits set by the monarch. There is also the modern salafi trend linked to international violent Islamist networks. Finally there is the radical, but peaceful trend represented by the Justice and Charity Group ( $a l$ Adl). Being the most popular Islamist movement in Morocco, the latter group is semi-legal and refuses to partake in institutional politics because it would mean legitimising the King as Commander of the Faithful, which runs against the conviction of the Group that the monarch has no such religious legitimacy. ${ }^{54}$ This means that 'the popularity of the fundamental opposition rhetoric of Justice and Charity among Islamist constituencies has kept the PJD from mobilising wide segments of the disenfranchised population'. ${ }^{5}$ The fragmentation of the Islamist camp is an asset for the regime and its 'divide and rule' strategies. ${ }^{56}$ This makes the PJD radically different in terms of threat perception to the MB in Egypt.

Finally, the role of elections in Morocco is to provide a spectacle for international consumption and they are not meant to be meaningful expressions of the will of the people. Morocco has thrived since independence by being perceived as a pluralist polity. The international dimension of the legitimacy of the Moroccan regime should not be underestimated and Moroccan monarchs have traditionally been responsive to the expectations of the international community. Whilst a significant degree of authoritarianism was tolerated during the Cold War as Morocco was an ally of Western countries, the international political transformations of the early 1990s and social changes within Morocco required a change in the legitimising discourse of the Monarchy. The solution was found in the adoption of the language of democratization, whereby, under the prudent guidance of the Monarchy Morocco would be transiting from authoritarianism to some form of inclusive constitutional democracy underpinned by strong political parties and an active civil society. The international community encouraged and supported this top-down transition, ${ }^{57}$ as it was in line with its new pro-democracy foreign policies. Upon coming to power Mohammed VI deepened the reforms that Hassan II introduced late in his reign and presented his vision for Morocco as being based on the dual and mutually reinforcing dynamics of democratisation and development. Mohammed VI is in many ways no 
different from his father and has continued to integrate Morocco into Western economic and political structures, signing a free trade agreement with the US and deepening ties with the EU. ${ }^{58}$ In addition, Morocco has been an important partner in the 'war on terror'. All this has been possible partly because of the appearance of a gradual democratisation process taking place in the country. Even when the country was ruled with an iron fist by the monarch through the Makhzen, legislative multiparty elections were held and Léveau defined the country then as having a "political system based on authoritarian pluralism. ${ }^{59}$ Election results were fixed in advance of the contest in order for the King to be better able to distribute power and influence a complex system of patronage that would ultimately allow him to remain in control of most policy-making power. This strategy was quite successful and Hassan II was able to survive in power and, as Howe highlighted, 'Morocco [was] generally respected by world powers as a stable constitutional monarchy engaged in the democratic process and as an Islamic voice of moderation. ${ }^{60}$ Morocco is perceived as an advanced 'democratizer' and this reputation cannot easily be tarnished by electoral violence. In this context, legislative elections play an important role and their smooth running, fairness and international monitoring constitute a legitimising asset for the monarch. This is even more the case precisely because an Islamist party was allowed to run, strengthening the impression of genuine political change. Without this reputation, Morocco would not be able to extract as many benefits from the international community. Some would argue that appearing to be a 'democratizer' is not an important pre-condition for having good relations with the West and this is generally true, as the cases of neighbouring Tunisia and Algeria demonstrate. However, it is important to look at where each country stands in terms of international reputation. Morocco always thrived on presenting itself as a pluralist society with a multiparty system and obviously deviating from that would detract from its reputation. Tunisia and Algeria had a very different type of image abroad and therefore probably enjoyed more latitude when it comes to their reputation as democratizers.

The manipulation of the electoral process in 2007 did not paradoxically take place during the electoral process itself, as it had done in Egypt. Rather, such manipulation is inherent in the Moroccan political system where the constitutional role of the King, unelected and unaccountable to popular will, ensures that the elected officials have very little weight in determining policy-making. Thus, the 2007 elections can rightly be labelled free and fair, but certainly not as historic and 
breaking with the past as they have been presented. ${ }^{61}$ It follows that analysing the results and expecting on that basis to make meaningful inferences about the strength of political parties and the political views of ordinary Moroccans is misleading. ${ }^{62}$ The only piece of data that can tell us something about the electoral process is turnout, which was a shocking 37 percent in 2007 . This sharply contrasted with the efforts by the state, the political parties and the King himself to encourage participation after the already very low turnout figure of 51.6 percent in the 2002 legislative elections. In addition to poor turnout, one fifth of the votes cast were invalid, further reducing the percentage of Moroccans who actually participated in such 'historic elections.' The disaffection of voters towards the political system as a whole indicates that electoral contests do not represent an arena for meaningful confrontation and debate, thereby decreasing significantly the necessity for the regime to employ violence to fix their outcome. Paradoxically, abstention seems beneficial to the monarchy because it delegitimises the political parties rather than the monarch, as voters opt out of the system leaving the King in his unquestioned position of supreme power over all other political actors.

In conclusion, the absence of violence and of interference in the electoral process do not constitute signs of democratisation, but simply indicate that the manipulation strategy of the regime sees elections as central elements of international legitimacy and they should therefore be conducted with high standards. The 2007 elections were certainly an improvement on previous contests when vote-buying and fraud occurred on a massive scale and when some parties, as was the case for the PJD in 2002, were only partially able to compete freely. However, this does not substantially modify the decision-making balance in the political system, which is heavily tilted towards the monarchy. In this context, it is therefore obvious that violence from both state authorities and from autonomous political groups would be extremely damaging for the image of Morocco and for its self-perception. On the one hand, the monarch and the security apparatus refrain from using violent coercion and, increasingly, from practices such as ballot box stuffing because this would send the signal that the country is no longer on the road to democracy. On the other hand, widespread electoral violence on the part of political movements would indicate not only that the state is not in control, but, more crucially, that there is strong opposition to elections per se, once again presenting an image of instability that the monarchy is very keen to avoid. 


\section{Conclusion}

Far from being antithetical, elections and violence are often intertwined. This is particularly the case, as one would expect, in conflict-ridden societies and liberalising countries. It is increasingly, however, a phenomenon that is also encountered in fullyfledged authoritarian regimes. Whilst there is a significant amount of scholarship dealing with the question of why authoritarian leaders even bother holding elections in the first place, this article attempts to explain under which conditions rulers employ violence once the electoral process has begun. Whilst the electoral potency of the opposition is certainly an important element in the rational calculus that rulers make when deciding to employ or refrain from the use of force in elections, there are other factors that need to be taken into account. It is necessary first of all to analyse the relative importance of the institution for which elections are called for. Second, there is the need to examine the alternatives that a regime has in order to influence the outcome of elections. Finally, in an increasingly interdependent world, one has to take into account the reactions of the international community.

The cases of the legislative elections in Egypt in 2005 and in Morocco in 2007 provide strong empirical evidence for the validity of the theoretical framework built around the three variables outlined above. Within this framework, it is quite unsurprising that the Mubarak regime decided to resort to violence to manage the 2005 legislative elections. The importance of parliament in the Egyptian institutional setting, the absence of alternatives to violence such as fraud so late in the game and the knowledge of the support from the international community for the crackdown compounded the electoral potency of the Muslim Brotherhood. The use of violence was both rational and effective. The absence of electoral violence in Morocco is equally unsurprising given the weak role parliament plays in the Moroccan political system, the existence of viable alternatives to influence the outcome and the reliance of Morocco on an international image of a much stronger 'democratiser' than Egypt. Unlike in the Egyptian case, electoral violence would undermine the Moroccan regime. The paradox of it all is that the rulers of Morocco and Egypt share similar domestic and international constraints and they should therefore behave in a similar manner when faced with domestic challenges. This is obviously not the case and as Albrecht and Wegner highlighted in their work on Islamism in the two countries, institutions matter ${ }^{63}$ and significantly influence choices like the use of violence during 
elections. The findings from Morocco and Egypt point to the necessity of looking beyond the threat of opposition potency when explaining electoral violence and they can be used to better understand how political institutions shape the responses of rulers facing similar domestic challenges.

Acknowledgements: Francesco Cavatorta wishes to acknowledge the financial support received from the Dublin City University Career Start Programme in carrying this research out. He also wishes to thank the colleagues of the Centre for Contemporary Middle East Studies at the University of Southern Denmark for their hospitality during the academic year 2008/2009.

\section{Bibliography}

Abaza, Khairi. 'Political Islam and Regime Survival'. Policy Focus 51, (2006): 1-24.

Albrecht, Holger. 'How Can Opposition Support Authoritarianism: Lessons from Egypt'. Democratisation 12, no. 3 (2005): 378-397.

Albrecht, Holger and Eva Wegner. 'Autocrats and Islamists: Contenders and Containment in Egypt and Morocco'. The Journal of North African Studies 11, no. 2 (2006): 123-141.

Amar, Ali. Mohammed VI. Le Grand Malentendu. Paris: Calmann-Lévy, 2009.

Baaklini, Abdo, Guilain Denoeux and Robert Springborg, eds. Legislative Politics in the Arab World: The Resurgence of Democratic Institutions. Boulder, Colorado: Lynne Rienner Publishers, 1999.

Beau, Nicolas and Catherine Graciet. Quand le Maroc Sera Islamiste. La Découverte, 2006.

Ben-Layashi, Samir. 'Morocco's 2007 Elections: A Social Reading'. Middle East Review of International Affairs 11, no. 4 (2007): 72-78.

Brumberg, Daniel. 'The Trap of Liberalised Autocracy'. Journal of Democracy 13, no. 4 (2002): 56-68.

Burgat, Francois. 'Les élections législatives marocaines du vendredi 7 septembre 2007 ou le jouet cassé', Mensuel de l'Université, December 1 2007, $\mathrm{http}: / / w w w . l e m e n s u e l . n e t / 2007 / 12 / 01 /$ les-elections-legislatives-marocaines-du-vendredi-7septembre-2007-ou-le-jouet-casse (accessed April 22, 2009).

Cavatorta, Francesco, Raj Chari, Sylvia Kritzinger and Arantza Gomez. 'EU External PolicyMaking and the Case of Morocco: Realistically dealing with Authoritarianism?'. European Foreign Affairs Review 13 (2008): 357-376.

Cavatorta, Francesco 'More than Repression; Strategies of Regime Survival: The Significance of Divide et Impera in Morocco'. Journal of Contemporary African Studies 25, no. 2 (2007b): 187-203.

Chase, Robert S., Emily B. Hill and Paul Kennedy, 'Pivotal States and US Strategy'. Foreign Affairs (January/February 1996): 33-51. 
Davenport, Christian. 'From Ballots to Bullets: An Empirical Assessment of How National Elections Influence State Uses of Political Repression'. Electoral Studies 16, no. 4 (1997): 517-540.

Davenport, Christian. 'Multi-Dimensional Threat Perception and State Repression: An Inquiry into Why States Apply Negative Sanctions'. American Journal of Political Science 39, no. 3 (1995): 683-713.

Denoeux, Guilain P. 'Corruption in Morocco: Old Forces, New Dynamics and a Way Forward'. Middle East Policy 14, no. 4 (2007): 134-151.

Denoeux, Guilain P. and Helen Desfosses. 'Rethinking the Moroccan Parliament: The Kingdom's Legislative Development Imperative', Journal of North African Studies 12, no. 1 (2007): 79-108.

Diamond, Larry. 'Elections Without Democracy: Thinking about Hybrid Regimes.' Journal of Democracy 13, no. 2 (2002): 21-35.

Durac, Vincent. 'The Impact of External Actors on the Distribution of Power in the Middle East: the Case of Egypt'. The Journal of North African Studies 14, no. 1 (2009): 75-90.

Egyptian Association for Supporting Democratic Development. Press Releases 1 - 3, Cairo: 26 November 2005, http://www.ndi.org/libraryquicksearch?op0=\%3D\&filter0=egypt (accessed 25 February 2009).

Egyptian Organisation for Human Rights. Future Parliamentary Victims: EOHR's Report on Fact-Finding Mission to Monitor Results for 2005 Future Parliamentary Victims in the Governorates, Cairo: 30 January 2006, http://www.eohr.org/report/, (accessed 27 February 2009).

Egyptian Organisation for Human Rights. 2005 Parliamentary Elections Initial Report: Third Phase Round One, Cairo: 1 December 2005, http://www.eohr.org/report/ (accessed 27 February 2009).

El-Mikawy, Noha. The Building of Consensus in Egypt's Transition Process. The American University in Cairo Press, 1999.

Ezzat, Dina. 'Marriages of Convenience'. Al-Ahram Weekly, 29 December 2005 - 4 January 2006.

Friedrich Ebert Stiftung. Political and Electoral Violence in East Africa, Working Papers on Conflict Management, No. 2, 2001, http://library.fes.de/pdf-files/bueros/kenia/01398.pdf (accessed 14 May 2009)

Gartner, Scott Sigmund and Patrick M. Regan. 'Threat and Repression: The Non-Linear Relationship between Government and Opposition'. Journal of Peace Research 33, no. 3 (1996): 273-287.

Hamzawy, Amr and Nathan J. Brown. 'Can Egypt's Troubled Elections Produce a More Democratic Future'. Carnegie Endowment for International Peace, December 2005, http://www.mafhoum.com/press9/262S24.pdf (accessed June 12, 2009).

Hamzawy, Amr. 'The 2007 Moroccan Parliamentary Elections: Results and Implications'. Carnegie Endowment for International Peace, September 11, 2007, 
http://www.carnegieendowment.org/files/moroccan_parliamentary_elections_final.pdf (accessed June 12, 2009).

Hoeglund, Kristine. 'Electoral Violence in Conflict-Ridden Societies: Concepts, Causes and Consequences'. Terrorism and Political Violence 21, no. 3 (2009): 412-427.

Howaidy, Amira. 'The MB Conundrum'. Al-Ahram Weekly, 10-16 November 2005.

Howe, Marvine. 'Fresh Start for Morocco'. Middle East Policy 8, no. 2 (2001): 59-67.

Human Rights Watch. Bullets for Each of You" - State-Sponsored Violence since Zimbabwe's March 29 Elections, June 2008, http://www.hrw.org/en/reports/2008 (accessed 14 May 2009).

Jordan, B. J. and Robert J. Pauly Jr. 'The Centrality of Egypt to the Future of the Greater Middle East'. In Strategic Interests in the Middle East: Opposition or Support for US Foreign Policy, eds. Jack Covarrubias and Tom Lansford, Burlington: Ashgate, 2007.

Kohstall, Florian. 'Reform Pirouettes: Foreign Democracy Promotion and the Politics of Adjustment in Egypt'. Internationale Politik und Gesellschaft 3 (2006): 32-45.

Konrad Adenauer Foundation, Die Aegyptischen Parlamentswahlen 2005: III. Wahlgang, 22 December 2005, http://www.kas.de/proj/home/pub/18/1/year-2005/dokument_id7763/index.html (accessed 12 April, 2009).

Kriger, Norma. 'Zanu(PF) Strategies in General Elections, 1980-2000: Discourse and Coercion'. African Affairs 104, no. 414 (2005): 1-34.

Langohr, Vicky. 'Cracks in Egypt's Electoral Engineering: The 2000 Vote'. Middle East Report (November 2000). http://www.merip.org/mero/mero110700.html, (accessed 26 September 2009).

Langohr, Vicky. 'An Exit from Arab Autocracy'. Journal of Democracy 13, no. 3 (2002): 116-122.

Laskier, Michael M. 'A Difficult Inheritance: Moroccan Society under King Mohammed VI'. Middle East Review of International Affairs 7, no. 3 (2003): 1-20.

Léveau, Remi. 'Morocco at the Crossroads'. Mediterranean Politics 2, no. 2 (1997): 95-113.

Linantud, John L. 'Whither Guns, Goons and Gold? The Decline of Factional Electoral violence in the Philippines'. Contemporary East Asia Studies 20, no. 3 (1998): 298-318.

Makram-Ebeid, Mona. 'Egypt's 2000 Parliamentary Elections'. Middle East Policy 8, no. 2 (2001): 32-44.

Makram-Ebeid, Mona. 'Egypt's 1995 Elections: One Step Forward, Two Steps Back?' Middle East Policy 4, no. 3 (1996): 119-136.

Ottaway, Marina and Meredith Riley. 'Morocco: From Top-Down Reform to Democratic Transition'. Carnegie Papers 71 (2006): 3-20.

Raftopoulos, Brian. 'Briefing: Zimbabwe's 2002 Presidential Election'. African Affairs 101 (2002): 413-426. 
Rakkah, Azzédine. 'Les trois leçons des élections marocaines'. CERIUM, University of Montreal, September 26, 2007, http://www.cerium.ca/spip.php?page=impression\&id_article=5106 (accessed June 12, 2009)

Rapoport, David C. and Leonard Weinberg. 'Elections and Violence'. Terrorism and Political Violence 12, no. 3 (2000): 15-50.

Richter, Donald. 'The Role of Mob Riot in Victorian Elections, 1865-1885'. Victorian Studies 15, no. 1 (1971): 19-28.

Rutherford, Bruce, K. Egypt after Mubarak: Liberalism, Islam and Democracy in the Arab World. Princeton University Press, 2008.

Schedler, Andreas. 'The Menu of Manipulation'. Journal of Democracy 13, no. 2 (2002): 3650 .

Singerman, Diane. 'The Politics of Emergency Rule in Egypt'. Current History 101, no. 651 (2002): 29-35.

Snyder, Jack. From Voting to Violence: Democratisation and Nationalist Conflict. New York: Norton, 2000.

Storm, Lise. 'Testing Morocco: The Parliamentary Elections of September 2007'. Journal of North African Studies 13, no. 1 (2008): 37-54.

Storm, Lise. 'The Parliamentary Election in Morocco, September 2007'. Electoral Studies 27 (2008): 359-364.

Sullivan, Denis. 'Will the Muslim Brotherhood Run in 2010?', Arab Reform Bulletin May 2009, http://www.carnegieendowment.org/arb/? fa $=$ show\&article $=23057$ (accessed 8 May, 2009).

Thabet, Hala G. 'Egyptian Parliamentary Elections: Between Democratization and Autocracy'. African Development 31, no. 3 (2006): 11-24.

Trisko, Jessica. N. 'Coping with the Islamist Threat: Analysing Repression in Kazakhstan, Kyrgyzstan and Uzbekistan'. Central Asian Survey 24, no. 2 (2005): 373-389.

Tronvoll, Kjetil. 'Voting, Violence and Violations: Peasant Voices on the Flawed Elections in Hadiya, Southern Ethiopia'. Modern African Studies 39, no. 4 (2001): 697-716.

United States Congressional Research Service. Egypt: 2005 Presidential and Parliamentary Elections. Washington 15 January 2006, http://fpc.state.gov/c18192.htm (accessed 3 March, 2009).

US State Department, Daily Press Briefing by Sean McCormack), Washington DC, 10 September 2007, reprinted by African Press Organization, http://appablog.wordpress.com/2007/09/10/parliamentary-elections-in-morocco/, accessed 23 April, 2009).

US State Department, Daily Press Briefing by Sean McCormack, Washington DC, 30 November 2005, http://2001-2009.state.gov/r/pa/prs/dpb/2005/57483.htm, (accessed 20 February, 2009). 
US State Department, Daily Press Briefing by Sean McCormack, Washington DC, 8 September 2005, http://2001-2009.state.gov/r/pa/prs/dpb/2005/52801.htm, accessed 20 February, 2009).

White, Gregory. 'Free Trade as a Strategic Instrument in the War on Terror? The 2004 USMoroccan Free Trade Agreement'. Middle East Journal 59, no. 4 (2005): 597-616.

Wilkinson, Steven. I. Votes and Violence: Electoral Competition and Ethnic Riots in India. Cambridge University Press, 2004.

Willis, Michael J. 'Political Parties in the Maghrib: Ideology and Identification. A Suggested Typology.' The Journal of North African Studies 7, no. 3 (2002): 1-28.

Willis, Michael J. 'Morocco's Islamists and the Legislative Elections of 2002: The Strange Case of the Party that Did Not Want to Win'. Mediterranean Politics 9, no. 1 (2004): 53-81.

Wolff, Sarah. 'Constraints on the Promotion of the Rule of Law in Egypt: Insights from the 2005 Judges' Revolt'. Democratization 16, no. 10 (2009): 100-118.

Zartman, William. 'Opposition as Support of the State'. In The Arab State, ed. Giacomo Luciani. University of California Press, 1990.

\section{Notes}

${ }^{1}$ Richter, 'The Role of Mob Riot'; Rapoport and Weinberg, 'Elections and Violence'.

${ }^{2}$ Rapoport and Weinberg, 'Elections and Violence', 16-17.

${ }^{3}$ Hoeglund, 'Electoral Violence'; Linantud, 'Whither Guns'; Snyder, From Voting to Violence; Wilkinson, Votes and Violence.

${ }^{4}$ Tronvoll, 'Voting, Violence and Violations'; Raftopouls, 'Zimbabwe's 2002 Presidential Election'; Kriger, 'Zanu(PF) Strategies'.

${ }^{5}$ Schedler, 'The Menu of Manipulation', 42.

${ }^{6}$ Brumberg, 'The Trap of Liberalised Autocracy'.

${ }^{7}$ Gartner and Regan, 'Threat and Repression', 275.

${ }^{8}$ Non-democracies are regimes that do not fulfil the minimum requirements of electoral democracy, as defined by Schumpeter (1947) and Przeworski (2000). Typically such regimes either (1) do not hold competitive legislative/executive elections altogether, (2) hold non-competitive single party elections only, or (3) allow for limited multiparty contestation, yet under conditions that are neither free and fair nor allow for the possibility of power alternation. See Przeworski, et al., Democracy and Development, 28-29; Schumpeter, Capitalism, Socialism and Democracy, 269.

${ }^{9}$ See also Friedrich Ebert Stiftung, Political and Electoral Violence, and Human Rights Watch, Bullets for Each of You.

${ }^{10}$ Diamond, 'Elections without Democracy'.

${ }^{11}$ Zartman, 'Opposition as Support' and Albrecht, 'How Can Opposition Support Authoritarianism'.

${ }^{12}$ Albrecht and Wegner, 'Autocrats and Islamists'.

${ }^{13}$ Davenport, 'From Ballots to Bullets', 521.

${ }^{14}$ Gartner and Regan, 'Threat and Repression', 277.

${ }^{15}$ Chase et al., 'Pivotal States' and Trisko, 'Coping with the Islamist Threat'.

${ }^{16}$ Hamzawy and Brown, 'Can Egypt's Elections Produce', 2-3.

${ }^{17}$ See for instance the United States Congressional Research Service, Egypt: 2005 Presidential and Parliamentary Elections.

${ }_{18}$ Abaza, 'Political Islam', 14. In contrast to past elections for instance, not a single Brotherhood candidate or supporter was arrested during the election campaign. See Howaidy 'The MB Conundrum'.

${ }^{19}$ Some accounts put the figure at 13 election-related deaths. See United States Congressional Research Service, Egypt: 2005 Presidential and Parliamentary Elections. 
${ }^{20}$ Due to a shortage of judges to supervise the polling stations, the government in 2000 decided to spread the voting process over three phases. In the 2005 elections the three rounds of voting were held between 9 November and 9 December.

21 A detailed account of the violence marring the voting process during the 2005 parliamentary elections can be found in a number of monitoring reports. See for instance Egyptian Association for Supporting Democratic Development, Press Releases 1 - 3 and Egyptian Organisation for Human Rights, 2005 Parliamentary Elections Initial Report: Third Phase Round One.

${ }^{22}$ Albrecht and Wegner, 'Autocrats and Islamists'.

${ }^{23}$ Rutherford, Egypt after Mubarak.

${ }^{24}$ Gartner and Regan, 'Threat and Repression', 275-276; Davenport, 'Multi-Dimensional Threat Perception'.

${ }^{25}$ Langohr, 'An Exit from Arab Autocracy', 117. Officially, the Muslim Brotherhood is a banned Islamist organisation.

26 Makram-Ebeid, 'Egypt's 1995 Elections' and Makram-Ebeid, 'Egypt's 2000 Parliamentary Elections'. Since 1990, parliamentary elections in Egypt are held on the basis of a majority run-off system in 222 two-member constituencies.

${ }^{27}$ As in past elections, in 2005 the MB focussed its campaigning efforts on brotherhood strongholds. It also refrained from placing candidates against government heavyweights as a measure of appeasement. Observers have noted that because the MB targeted primarily 'safe' constituency seats, the 2005 results may not reflect the actual electoral support the group carries in the entire country. See Ezzat 'Marriages of Convenience'.

${ }^{28}$ These included 44 so called NDP independents, which after having failed to secure their party's nomination, had opted to contest the elections outside the formal NDP umbrella.

${ }^{29}$ Egypt abrogated the one-party system in favour of limited multiparty elections in 1979.

${ }^{30}$ State-sponsored violence apart, in rounds two and three of the elections the security forces arrested over $1000 \mathrm{MB}$ cadre and sympathisers, closed polling stations prematurely and prevented voters from casting their ballot. See Sullivan 'Will the Muslim Brotherhood Run in 2010?'.

31 A detailed analysis of the powers of the Egyptian legislature can be found in Baaklini et al., Legislative Politics in the Arab world and El-Mikawy, The Building of Consensus, 97-125.

32 Egypt has been governed under emergency rule between 1967 and 1980, and again after the assassination of Sadat from 1981 onwards. Emergency legislation was last renewed by parliament for a two-year period in 2008.

${ }^{33}$ Singerman, 'The Politics of Emergency Rule', 29-30.

${ }^{34}$ Wolff, 'Constraints on the Promotion', 104.

${ }^{35}$ Makram-Ebeid, 'Egypt's 2000 Parliamentary Elections' and Langohr, 'Cracks in Egypt's Electoral Engineering'.

${ }^{36}$ See US State Department, Daily Press Briefing by Sean McCormack (8 September 2005).

${ }^{37}$ Jordan and Pauly, 'The Centrality of Egypt'.

${ }^{38}$ Kohstall, 'Reform Pirouettes', 33.

${ }^{39}$ See US State Department, Daily Press Briefing by Sean McCormack, (30 November 2005).

${ }^{40}$ Ibid.

${ }^{41}$ Durac, 'The Impact of External Actors'.

${ }^{42}$ Storm, 'Testing Morocco', 38.

${ }^{43}$ Willis, 'Morocco's Islamists'.

${ }^{44}$ Storm, 'Testing Morocco', 41.

${ }^{45}$ Ben-Layashi, 'Morocco's 2007 Elections', 72.

${ }^{46}$ Storm, 'The Parliamentary Election', 359.

${ }^{47}$ See for instance the US State Department, Daily Press Briefing by Sean McCormack (10 September 2007).

${ }^{48}$ Denoeux and Desfosses, 'Rethinking the Moroccan Parliament, 79.

${ }^{49}$ See Le Journal Hebdomadaire 23/4/2005.

${ }^{50}$ Amar, Mohammed VI.

${ }^{51}$ Storm, 'The Parliamentary Election'.

${ }^{52}$ Willis, 'Political Parties in the Maghrib'.

${ }^{53}$ Laskier, 'A Difficult Inheritance'.

${ }^{54}$ Beau and Graciet, Quand le Maroc Sera Islamiste and Zeghal, Les Islamistes Marocains.

${ }^{55}$ Hamzawy, 'The 2007 Moroccan Parliamentary Elections', 4.

${ }^{56}$ Cavatorta, 'More than repression'.

${ }^{57}$ Ottaway and Riley, 'Morocco'. 
${ }^{58}$ On the US-Morocco relations see White, 'Free Trade as a strategic instrument'. On the EU-Morocco relations, see Cavatorta et al. 'EU External policy-making'.

${ }^{59}$ Léveau, 'Morocco at the Crossroads', 95.

${ }^{60}$ Howe, 'Fresh Start', 59.

${ }^{61}$ See for instance the declaration by Marina Ottaway Middle East Program director at the Washingtonbased Carnegie Endowment for International Peace: 'these elections are historic for Morocco--and the international community--since there's a good chance that an Islamist party will emerge as the single most important party.' The statement is available at http://www.awid.org/eng/Issues-and-

Analysis/Library/Elections-Put-Moroccan-Women-at-Crossroads/(language)/eng-GB Accessed On November 19th 2009. See also how the EU validated the elections as both transparent and aimed at strengthening the process of democratization. The statement in French is available at http://europa.eu/rapid/pressReleasesAction.do?reference=MEMO/08/211\&format=HTML\&aged=0\&la nguage $=$ EN\&guiLanguage $=$ en .

${ }^{62}$ See Burgat 'Les élections législatives marocaines du vendredi 7 septembre 2007 ou le jouet cassé'.

${ }^{63}$ Albrecht and Wegner, 'Autocrats and Islamists' 